\title{
A Brief Exploration of the Development of Business English Major in China — Challenges and Opportunities
}

\author{
Bayan Ruan \\ Ningbo Institute Technology, Zhejiang University, China; \\ The University of Nottingham, China campus, Ningbo, China
}

\begin{abstract}
The issue of Business English (BE) Major development is currently being discussed hotly in China since it has been officially approved by Chinese Education Ministry about twelve years ago. This paper takes a historic overview and explores the reasons about why BE major is necessary in China's higher education institutions, including discussion on BE's definition in China context, its relationship with English for Specific Purpose (ESP). Through combining ESP's popular theory - NAT (need analysis theory), the paper concludes problems raised during the development of $\mathrm{BE}$ major in China, including disputations about its curriculum design, learners' dissatisfaction, and BE teachers' professional development. Further application discussion on NIT's BE major (Ningbo Institute Technology, Zhejiang University, where the author is working at) will also be shown in the later part. This paper suggests to design curriculum that are suitable to China's different levels of universities rather than to merely learn from good universities either abroad or domestically. The paper then calls for a further exploration specifically in terms of improving curriculum design and BE teachers' professional development.
\end{abstract}

Index Terms-Business English, Business English Major, English for Specific Purpose, Need Analysis Theory, teachers' professional development

\section{INTRODUCTION}

The development of Business English (BE) Major in Chinese Colleges and universities is currently facing huge significant opportunities as well as huge challenges. On the one hand, BE teaching has recently swept the country as it is vigorously developing in higher education institutions. On the other hand, the orientation of BE major has not yet been established, and thus a complete BE major curriculum system has not been formed officially in $\mathrm{China}$ (Fu, 2006). Therefore, it seems that the task of constructing BE major in China is still arduous. In this situation, it can be the first priority to take a road with Chinese characteristics on BE major development since there is no equivalent abroad by strengthening its theoretical and practical study both at home and abroad, and analyzing its specific situation of construction in China's higher education institutions. This paper, then, will first provide the background information about the reasons on why BE major is necessary in China and its historic overview. A literature review on the definition of BE, its relationship with English for Specific Purpose (ESP), and problems raised during its development including disputations about curriculum design, learners' satisfaction, and BE teachers' development will be shown. Finally, an application discussion on these disputes will be further explained, followed by a very brief conclusion.

\section{BACKGROUND}

\section{A. The Necessity of Having BE Major in China}

After 30 years of economic growth and social development, China has become the world's second-largest economy whose influence over global affairs is growing rapidly. The country has been transformed at a rate and on a scale perhaps unprecedented in human history. Up to the year 2014, China's foreign investment has already exceeded 4 trillion and 300 billion yuan or RMB (Wang, 2015), and in 2016, it is for the first time that China's outward investment exceeded the inward investment, becoming a net capital exporter (Center for China and Globalization (CCG), Social Sciences Academic Press (China), 2016). What is more, the Chinese government has put forward the grand strategy of expanding the opening to the outside world, for instance, building "One Belt, One Road (OBOR)" . With the grand strategy, it is projected that China will further integrate herself into the world economy and strengthen her influence across the world. However, it is worth mentioning that China's economic internationalization is still facing enormous challenges of talent shortage. In other words, if Chinese enterprises want to go to the outside world, they are in urgent need of a large number of international compound talents, who are professional in overseas investment, laws, finance,

\footnotetext{
${ }^{1}$ One Belt, One Road (OBOR): it refers to SREB (Silk Road Economic Belt) and MSR (Maritime Silk Road in the $21^{\text {st }}$ Century), the former links China and Europe via Western and Central Asia, the latter connects China with countries in Europe, Africa and Southeast Asia.
} 
trade, asset management, operation management, marketing, public relations and cultural integration and so forth. According to a survey done by Chinese Ministry of Commerce in 2014, within China, the number of qualified talents in international management and international investment management is only about 8,000 respectively, and there are merely around 2,200 qualified talents in international economy and law (Wang, 2015). "Qualified" here means those talents are proficient in using English language, as well as knowing the professional and specified related business knowledge in terms of trade, investment, finance, laws and so on (ibid.). From this perspective, those Chinese enterprises that want to go out of the country for doing transnational investment and management, are confronted with a situation that is in large shortage of international top talents. However, it might be true that China's current higher educational system and talent training mode cannot adapt to China's opening up policy and thus cannot satisfy the demand of talents for social and economic development. That is, the current higher education school-running orientation and teaching contents of English major need reforming (English Group of the Teaching Guiding Committee for College Foreign Language Majors under the Ministry of Education, 2000).

In response to the requirements of talents for satisfying China's social and economic development, in 2006, Chinese Ministry of Education started to approve the establishment of BE major undergraduate (Wang, 2015). Actually, before that year, many colleges and universities already had BE courses, but it was set under English major. In 2007, the Ministry of Education approved the University of International Business and Economics (UIBE) as the first university in China to run a pilot scheme on having BE major, which is independent of traditional English majors or English literature majors (Xu, Dong and Feng, 2011). This not only officially admitted the independent disciplinary status of BE major, but also ended the disputation and doubt on BE in academic area, legalizing BE major's popular status. Recently, according to a report in Hangzhou on December 16-18, 2016, which was hosted by the most influential BE researchers in China, Guo Jiahang and Wang Lifei both pointed out that the number of universities and colleges that have been approved officially by Chinese Education Ministry to have BE major is increased to 293 from 2007 to 2016 (Business English Major Teaching Cooperative Group under the Ministry of Education, 2016), and this might be the most recent and correct data since they are the most famous professors in BE area in China. In 2009, Teaching Requirement of Business English Major Undergraduate in Universities was published by the combination work of China's Higher Education Press and the University of International Business and Economics (UIBE). This requirement to some extent provides a theoretical guidance for the development of BE in China. All these efforts above indicate that Chinese higher education system is promoting, exploring and standardizing the construction of BE major.

\section{B. BE Historic Overview in China}

The development of BE in China has more than 60 years' history. According to Chen (2001), the first university that had BE courses was related to translation in the field of foreign trade of personnel training. In the 1950s, Zhang (2007) said that textbooks were used and taught either by teachers together with business people or by experienced teachers, and materials used in these textbooks were selected from the real business transaction, or mimicking the real business procedures, and the lessons were much more the same as nowadays (i.e. "establishing business relations, making enquiries, offers and counter-offers, and various exercises such as translation of business terms or sentences and letter writing."). However, it seems that Zhang did not make it clear about whether these experienced teachers have rich experience in business area or only in English language teaching area.

In the 1980s, China's opening up policy, which in turn requires business students not only have to learn language skills, but also have to be familiar with the practical ways of doing business. Multiple choices of courses such as management, marketing, international cooperation and so on were added. Thus, students may learn the language skills through the instruction of English mediation or English-mediated instruction on a business context (Zhang, 2007).

The 1990s may be called the booming times for BE since the number of universities providing BE courses increased dramatically. In order to promote multi-talents [复合型人才] that differ from literature and linguistic focused English major, BE courses were accredited by Chinese Ministry of Education (He, Yin, Huang, \& Liu, 1999).

In the 2000s to 2007, it was seen as a trend of upgrading BE course curriculum design (Zhang, 2007). For example, Wang and $\mathrm{Xu}$ (1997) called for a "two-stage curriculum", which mainly emphasizes on both language skills and business subject related content. Chen (1999) proposed a more systematic curriculum, and arguing that language skills and business subject knowledge could be united as a whole. In 2000, UIBE had courses such as: "western economics", "business ethics, "business law", but language skills and business subjects were still autonomous and independent (Zhang, 2007). This is to say, language skills courses were rather largely concerned with English language itself, and inadequately include professional business disciplinary context.

Moreover, since the official establishment of BE major in China, the construction of BE on a professional level has become the largest domestic hot spots for researching (Wang and $\mathrm{Li}, 2013$ ). However, up to now there seems to have no standard syllabus on a national level to guide the development of BE major in China. Since the orientation of BE major has not yet been fully established, a complete BE curriculum system has not been formed in Chinese colleges and universities (Fu, 2006). At present, each college or university tends to have their own syllabus. In this situation, strengthening the research on the theory and practice of BE domestic development, analyzing the specific situation of BE major construction in Chinese colleges and universities have become a pressing matter of the moment. As Chen (2010) pointed out that the main problems that plague BE major undergraduate development is how to allocate and 
grasp correctly its subject attribute, training mode, curriculum system, teaching principles and teachers development, and he further maintains that the essence of doing this is whether to emphasis more on "English" or "business". Above all, it seems that BE major teaching in China is still lacking a coherent theoretical framework, and since a national standard will be made public, this issue might be addressed.

\section{LITERATURE REVIEW}

\section{A. BE and ESP}

So, in order to build a better coherent theoretical framework, it is quite necessary to figure out what is really BE, and what is the best way to teach BE and how. In the next part BE's definition, and its relationship with ESP will be provided.

It should be noted that up to the $20^{\text {th }}$ century, there was an increased demand for BE worldwide, yet not so many studies published on BE, and those studies only focused on ESP--English for Specific Purpose (St John, 1996). ESP was first developed as a key improvement in English teaching in the 1960s. It was first pointed out by Halliday, Mcinfash and Strevens (1964) as English for specialists such as civil servants, policemen, nurses, engineers, officials of the law and so forth. In the book called English for Specific Purposes written by Hutchinson and Waters, ESP was defined as "an approach to language teaching in which all decisions as to content and method are based on the learner's reason for learning" (Hutchinson and Waters, 1987, p.19). ESP usually differs from EGP (English for General Purpose) in terms of curriculum design and material selection (Zhang, 2007); and there also exit differences between EGP and BE, the former is mainly for training language ability, whereas the latter mainly aims at improving better communication in business context (Ellis and Johnson, 1994). Many foreign scholars admit that BE belongs to ESP (i.e. Hutchinson \& Waters, 1987; Robinson, 1991; Johns\& Dudley-Evans, 1991; St. John \& Johnson, 2002; Zagan-Zelter, 2010). Many Chinese scholars also admit this as well. For instance, Li (2014) pointed out that BE contains three aspects so far: it belongs to ESP and thus is one type of ESP; it is under English major as it has a social functional variety; it is an independent major or discipline. Dou (2005) gives a definition on BE by saying that it is one type of ESP, which is based on English language as a medium, and centered on business knowledge. Hence, it is widely accepted that BE belongs to ESP. That is, BE may not exist alone without the development background of ESP, and research on BE need to largely obey ESP's theory.

However, some other scholars hold a different opinion on the view that BE belongs to ESP. For example, from linguistic perspective, Pickett (1986) states that BE is more like everyday language, rather than ESP. In terms of content, Ellis and Johnson (1994) argues that compared with other varieties of ESP, BE is quite different since it contains both general and specific content. Similarly, St John (1996) claims that BE encompasses English for General Business Purpose (EGBP: follow EFL, more likely to be pre-experience, open registration, extensive courses) and English for Specific Business Purposes (ESBP: largely be post-experience, intensive and company-based). What is more, domestic researcher Zhang (2007) argues that ESP cannot help to fully answer the question of what BE really is since BE also contains teachers' needs, and he declares that ESP is about language teaching to satisfy learner's communication need merely. This view is consistent with what Munby $(1978$, p.2) once defined ESP as "... those where the syllabus and materials are determined in all essentials by prior analysis of the communication needs of the learner, rather than by non-learner-centered criteria such as the teacher's or institution's predetermined preference for General English or for treating English as part of a general education". Moreover, Hutchinson and Waters (2002, p.19) also hold a similar view by claiming that "ESP ... is an approach to language learning, which is based on learner need." In other words, ESP may only offer framework of language teaching in order to satisfy learners' communication need rather than the study of English language in use in specific field such as business. Hence, it may be inferred that BE could be one branch of ESP, but it is also different from ESP as BE contains its own characteristics.

Yet, a perfect and completed definition of BE in China seems to have not reached agreement since there exist so many different versions. Considering Chinese specific background, this paper cited some typical famous Chinese scholars' views on BE definitions that have been widely accepted. For example, from the perspective of language as discourse, Zhang (2007, p. 406) gives a working definition on BE:

$B E$ involves the teaching of the system of strategic communication in the social and economic domain of international business in which participants, adopting/adapting business conventions and procedures, make selective use of lexico-grammatical resources of English as well as visual and audio semiotic resources to achieve their communicative goals via the writing modality, speaking modality, and/or multi-modality.

Based on the definition above, some key words may be extracted and concluded: systematic teaching (which may cover course designing and teaching method), international business knowledge, communication skills, English language and multi-modality (i.e. writing, speaking etc.). These key words appear to be consistent with many other scholars' views on BE major, but may still lacking another factor -- culture factor. Five years later, Wang (2012) defines $\mathrm{BE}$ as a lingua franca for international business communication. He emphasizes BE as a general language tool for better conducting business in international environment. Hence, his main focus of BE may still largely on English language itself. Also, Weng (2009) defines BE as an English language used for cross-cultural communication in international business activities; and BE major is an interdisciplinary major that aims at studying the discipline of business English teaching, the certain pattern of English used in international business environment. From Weng's definition, it can be 
inferred that in addition to previous English language and business knowledge, cross-cultural communication, namely, cultural issues are also included in BE major. Actually, this has already been mentioned by foreign experts in BE area. For instance, St John (1996) points out that BE needs an interdisciplinary method which consists of not only English language, business knowledge, but also interpersonal communication and cultural issues.

As a result, this paper may conclude that BE major requires both learners' needs and teachers' preference, it is a cross-disciplinarian major which covers not only English language, professional business knowledge, but also communication skills and intercultural issues.

\section{B. Need Analysis Theory (NAT)}

Need analysis theory (NAT) has been the cornerstone of ESP for a long time in terms of course design, programme planning, materials choice and assessment (Brown, 1995; Chambers, 1980; Dudley-Evans \& St. John, 1998; Ellis \& Johnson, 1994; Hutchinson \& Waters, 1987; Munby, 1978). It was first adopted in the book called English for Specific Purposes written by Hutchinson and Waters in 1987, information like "necessities, lacks, and wants" (p.55) are gathered in the needs analysis process, as well as the methods such as "questionnaire, interviews, observation, text collection and informal consultation" (p.58). They maintain that what distinguishes General English and BE is NAT, and NAT usually evolves three steps: plan, information collection and information analysis. Cowling (2007) claimed that multiple methods for collecting information can be used in needs analysis process. Moreover, NAT is widely considered as the very first stage and prerequisite of any curriculum designing, it is about processes include collecting information that can function as the ground for designing a curriculum that can satisfy the learners' need (Li, 2014). It seems that though NAT is considered as a key method in ESP, it can still be widely used in BE research.

\section{Dispute on Current BE Major According to NAT}

By utilizing NAT, studies abroad find out that there exist problems in terms of curriculum design, especially insufficient content of business knowledge. For example, Schleppegrell and Royster (1990) had done a survey of 55 schools that are providing English language teaching in the USA, Europe, the Middle East and Asia around the world in eleven cities, the final result of the survey indicates that the current programmes do not satisfy even the minimum criteria for ESP teaching since only " $38 \%$ using business-oriented instructional materials, $40 \%$ offering courses with goals that were specifically relevant to business professionals, and $47 \%$ incorporating business-oriented activities" (1990, p. 8-9). In other words, they think that business English need to cover more content on business knowledge related area. Another survey done by Louhiala-Salminen in 1996 through extensive questionnaires and interviews delivered among Finnish business professionals to explore their views on informants of writing communication in terms of language, structure and organization. The author mentioned that in reality, it is quite possible that good results will still be achieved even though the messages are linguistically poor, and BE teachers need to have enough knowledge on basic business formal document types such as contracts, orders and quotations and so on (Louhiala-Salminen, 1996). This survey to some extent infers that English language seems not as important as business knowledge in BE teaching since good results will still be achieved with enough business knowledge and poor linguistics. Moreover, researcher Zagan-Zelter (2010) applied NAT and suggested that students need a variety of courses that will help them in different business areas since it may be true that sometimes students will turn out to work in a totally different field that they majored in (i.e. accounting students working in tourism). He further finds out that BE teaching needs to focus more on language usage rather than on specific vocabulary, and also suggested continuous assessment to reassess students' needs, as well as reexamine course content. Here, "language usage" may refer to how to use language for better communication. Therefore, by using NAT, studies on BE abroad tend to find out that more business knowledge content, professional BE teachers, and better communication are needed.

By utilizing NAT, studies in China have also found similar problems in terms of curriculum design, and insufficient communication skills. For example, Zheng (2011) researched English major students' need of business English in Zhejiang University by conducting questionnaires to investigate factors such as selection of curriculum and material, evaluation of course assessment, preferences of teaching method, and needs of communication skills, one of the key findings is that the curriculum design cannot satisfy business English needs. Li (2014) argues that BE in China ignores students' personal interests and the needs from the society, which further leads to students' low motivation in BE learning and relatively poor language usage performance. This may be well reflected in Chinese students' low participation and less speaking during classes. It appears that current courses design may not well recognize the increasing demands of communication complexity, as a result, fail to satisfy students' needs. At the real workplace in Malaysia, an investigation was done by Moslehifara and Ibrahim, they delivered questionnaires to the HDR (human resources development) trainees, and find out that the importance of oral communication skills like social activities and interaction is well recognized by the trainees, thus, discussion, oral presentation, and conversation are needed in English training programs (Moslehifara and Ibrahim, 2012, p.536). Similarly, in China, Zhang (2014) concluded that business representatives need students to have three factors: cross-cultural awareness, international business knowledge and especially business communication skills. However, as Xie (2016) has pointed out that even students do have this awareness on improving communication skills, the real challenge goes to teachers. As a result, it seems that BE in China not only needs to improve curriculum design, but also need to add more content on improving communication skills and to promote the professional development of BE teachers in order to stimulate students' motivation. 


\section{Views on Whether to Learn from Either Abroad or Domestically}

Although there exists a dramatically growing demand on BE which can be seen as a great opportunity, BE major development tends to face significant challenges in China. In order to find out what the challenges are, and to optimize curriculum design, as well as train teachers, it may be reasonable that quite a lot of researchers recommended to learn the experience from the foreign countries since $\mathrm{BE}$ abroad has a relatively longer history and better development there. For example, Feng and Song (2011) did a survey in the University of Central Lancashire in the UK (the first university to have BE major in the UK), and they suggest to learn and copy the BE teaching mode from that British university by reforming domestic curriculum design, namely, by enhancing the teaching content of business knowledge and to change the original curriculum which is guided by English language teaching primarily and supplemented by business knowledge. However, many researchers (i.e. Dou, 2005; Sun and Bao, 2010) claim that considering China's specific situation, BE in China should have its own unique characteristics and development. Therefore, up to now, many domestic studies on BE tend to largely focus on figuring out a better BE curriculum. For instance, after a preliminary investigation on the curriculum design of BE major of more than 30 universities such as UIBE, Guangdong University of Foreign Studies and Shanghai Foreign Trade University, Chen (2010) found that the ideal curriculum model for China is: "General English courses (i.e. speaking, writing, listening, grammar, vocabulary, literature, etc.) + business English courses (i.e. Financial English, marketing English) + business professional courses (i.e. management, marketing, economics, and international finance study by using English language only)". He maintains that with a solid foundation of English language at year one or year two (China's undergraduate study mainly contains four years in total), students can move on smoothly to learn business English courses after year two, and finally succeeded in entering business professional knowledge with English language used as a medium only. His study may give a general idea of having a better curriculum model, yet he did not express clearly about how much percentage that the content of each course needs to have when it comes to the real application on the model.

The reality is that even the most successful universities in running BE major in China appear to have not designed an ideal curriculum. For instance, You and Zhang (2011) researched the three universities that have been admitted to have run BE major relatively successful in China ( the University of International Business and Economics--UIBE, Guangdong University of Foreign Studies, Shanghai Foreign Trade University), and they found out that there exits slight difference in terms of curriculum design among the three universities (see chart 1 below).

CHART 1. BASED ON YOU AND ZHANG (2011)'s SURVEY

\begin{tabular}{|l|l|l|l|}
\hline & English language & Business knowledge & culture \\
\hline UIBE & $56 \%$ & $32 \%$ & $12 \%$ \\
\hline Guangdong University of Foreign Studies & $60 \%$ & $30 \%$ & $10 \%$ \\
\hline Shanghai Foreign Trade University & $71 \%$ & $15 \%$ & $14 \%$ \\
\hline
\end{tabular}

As can be shown above, obviously, all the three universities have more English language courses, and are relatively deficient in professional business knowledge. You and Zhang (2011) then argue that even the curriculum design in the best universities cannot satisfy social needs since the business knowledge courses still accounts for too little. The lacking in theoretical construction and shortage of professional teachers are the main reasons (ibid.).

\section{DiscusSION}

According to the literature review, disputes on BE major in China seem to cover three aspects, namely, what to teach -- from the perspective of curriculum design, learners' dissatisfaction -- from students' point of view, and pressures from $\mathrm{BE}$ teachers. These three aspects will be further discussed by applying to the author's own working context below.

\section{A. Curriculum Design}

It may be true that after the official establishment of BE major in China, many domestic studies tend to largely focus on figuring out a better BE curriculum. However, problems appear to exceed the possible solutions. Hence, some researchers suggest learning and copying the teaching mode abroad since BE was developed much longer there. Yet, this suggestion may be not so ideal considering the different situations, including the level of English language proficiency and learners' background knowledge on business content. For example, Fu (2006) pointed out that studies on $\mathrm{BE}$ in English speaking countries show that they largely focus on improving language and skills rather than on adding more content about business knowledge. It may be true that business knowledge has not become the object of study in the English speaking countries though among the most recent studies, a wider attention has been focused on but only expanded on cultural awareness (Brieger, 1997) or cross-cultural communication (Dudley -Evans and St John, 1998). This may be because that there are two types of learners from native English speaking countries, namely, students majored in business and those learners who have real working experience (Ellis and Johnson, 1994). Accordingly, the purpose of learning BE in English speaking countries maybe not for increasing business knowledge as the learners already have grasped beforehand, but for improving language and skills for better communication in business context. Whereas in China, for instance, in Ningbo Institute Technology, Zhejiang University (NIT), where I am currently working at, learners of BE major are just students, and they are neither from business major nor having working experience before. Therefore, students of BE major in NIT may be unable to bring in business knowledge into 
the classroom themselves without being taught related knowledge by teachers. Hence, to totally learn and copy from abroad sounds unrealistic.

As a result, some domestic studies start to investigate the construction of BE major in Chinese universities (especially UIBE, Guangdong University of Foreign Studies, Shanghai Foreign Trade University) that are widely accepted as having run the BE major successfully, hoping to bring guidance and enlightenment to the better building of China's specific BE major. However, results from these studies may be for reference only, which means not all Chinese universities are suitable to apply to the teaching mode like these universities. On the one hand, it is true that China has so many different levels of universities and colleges, and not all the universities are as distinguished as the ones being mentioned earlier. That is, perhaps students' English level, teachers' team, universities' background and infrastructure can be quite different. For example, passing TEM 4 may not be a problem for students from those good universities (i.e. UIBE, Guangdong University of Foreign Studies, Shanghai Foreign Trade University), yet it would be a huge burden for those students from other not so distinguished universities, such as NIT. Accordingly, it might be better for those students from NIT to grasp the basic English language ability first before let them move on to the next stage that contains more business knowledge. On the other hand, findings in studies show that even the most successful universities in running BE major in China appear to have not designed an ideal curriculum. As the survey done by You and Zhang (2011) indicated that with insufficient business knowledge courses, the current curriculum design in the three universities still cannot satisfy social needs on professional BE talents. Hence, it is worth pointing out that as students' English language level being improved, more business knowledge could be added in China's good universities. However, for universities like NIT where I am working at, perhaps to grasp the basic English language knowledge is the first priority before moving on to add more business related content to the classes. Still, theoretical and practical framework is needed for further exploration in order to help China design ideal curriculums that are suitable and thus can be well applied to different levels of universities.

\section{B. Students'Dissatisfaction}

In terms of learners' dissatisfaction or students' low motivation, the main reason may be the immature development of BE major in China. Through NAT, Zhang and Wang (2012) concluded that students' motivation of learning business English includes employment after graduation, internal interest on English learning, personal development and external influence and so forth. This paper has given a definition on BE, that is, it covers not only English language, professional business knowledge, but also communication skills and intercultural issues. Nevertheless, as reflected in NIT, BE students appear to feel difficult in learning all the four aspects equal well. It may be true that as being non-native speakers, improving English language could be the basic requirement for Chinese BE major students, especially for those from universities like NIT. They may suffer lots of pressure on passing College English tests such as TEM 4 \& 8 . As Stanley (2011) reported that English language teaching in China is stressful under the assessment pressure, and it is also problematic in terms of class sizes, as well as teachers' inadequate competence of English language. Wette and Barkhuuizen (2009) also summarized that teachers in China have to satisfy both module requirements and students' needs in order to achieve excellent practices. The reality is that in NIT, sometimes teaching plan, curriculum design, and students' personal development needs are controversy. Thus, the development of communicative competence training in NIT tends to be marginalized as teachers have to bring in materials related to the language tests for having a higher passing rate in the country's national English language tests. Moreover, large size of students in Chinese classrooms may also cause students' discontent in learning BE, as in NIT, each class has at least 30 or more students. Simon (2014) once pointed out that in Romania, students' unwillingness to communicate during the class time could be the reasons that they lack autonomy and motivation to speak English out, and classroom arrangement may be external factor. Above all, in addition to the large size of classroom setting (which limited students' speaking choices), assessment pressure (students have to be pushed to spend time in passing the tests), the real challenge seems to go to BE teachers. In the next part, then, pressures from BE teachers will be further discussed.

\section{Pressures from BE Teachers}

As being reflected by many of my colleagues in NIT, it appears that BE teachers have suffered lots of burden in better developing Chinese BE major. On the one hand, currently many BE teachers in NIT are transferred from English major since BE major is quite new and thus is lacking related teachers. On the other hand, these BE teachers may lack business background knowledge that they can offer to students. Therefore, in order to adapt to the reformation of BE, BE teachers need to have professional development, especially in improving business knowledge. However, Ellis and Johnson (1994) argued that the first thing of being a business English teacher is to be an English language teacher, and it is the students that often bring professional business knowledge to the classroom. In other words, it may be not so important for BE teachers to have professional business knowledge. Dudley-Evans and St John (1998) agreed that BE teachers are not expected to be successful in running a business, just like doctors do not expect English teachers know how to be a doctor, instead, they expect that they can communicate fluently among doctors, patients, and nurses. Accordingly, BE teachers may be largely regarded as English language teachers, yet it should be noted that this is because as has been mentioned before, many of the BE learners abroad are from the real business companies, whereas learners are all inexperienced students who just graduated from senior high school and entered the university via Gaokao in China. Those learners abroad may already have the professional business knowledge and what they need is 
to learn how to use English language for better international communication. As a result, it may be not suitable to apply the idea (BE teachers are largely English language teachers) in China considering learning background, purpose of learning and learners' identity.

What is more, the purpose of learning BE abroad is generally for better communication, whereas it is now the requirement of the university education setting in China. Therefore, it is true that BE teachers in NIT suffer extra burden in professional development. As Ruan (2005) said that teachers should not only teach students' necessary business English knowledge and business knowledge, more importantly, they should cultivate students' abilities on using English knowledge and skills in different business contexts. That is, both English language knowledge and basic international business theoretical knowledge are required for BE teachers. Nevertheless, changing from general English major teachers to BE major teachers doesn't mean to change totally to the business area, but teachers in average universities in China, such as NIT, are required to learn some basic business knowledge for widening horizon in order to satisfy content-based teaching requirement. Therefore, how to build BE teachers professional development is worth for further exploration since this area appears to be significant and is regarded as a key factor in deciding the success of China's BE major development.

\section{CONCLUSION}

This paper has provided the background information on BE development in China, including its necessity, historic overview. Critically, the relationship between BE and ESP has been explained, followed by a BE definition. Later, based on the most popular theory in ESP area -- NAT, many studies have investigated the current problems on BE major in China, namely, lacking ideal curriculum models that are suitable to Chinese universities, learners' dissatisfaction or low motivation, and BE teachers' extra pressure. Instead of learning the curriculum from good universities either abroad or domestically, this paper suggests to design curriculum that are suitable to China's different levels of universities. The paper then calls for a further exploration specifically in terms of improving curriculum design and BE teachers' professional development.

\section{REFERENCES}

[1] Brieger, N. (1997). Teaching business English handbook. York: York Associates.

[2] Brown, J. D. (1995). The elements of language curriculum: a systematic approach to program development. Boston: Heinle and Heinle.

[3] Business English Major Teaching Cooperative Group under the Ministry of Education. (2016). Institution of Higher Education Business English Major Department Leaders' Joint Conference, 16-18 ${ }^{\text {th }}$ December, 2016, Hangzhou.

[4] Center for China and Globalization (CCG). (2016). Enterprise Internationalization Blue Book -- Chinese enterprise globalization Report, $23^{\text {rd }}$ November, 2016. Beijing Hanwei Plaza. Social Sciences Academic Press (China).

[5] Chambers, F. (1980). A re-evaluation of needs analysis in ESP. ESP Journal, 1(1), 25-33.

[6] Chen, Z. M. (1999). Towards a more systematic business English curriculum. In T. H. Lin (Ed.), Studies on International Business English in China. Xiamen: Xiamen University Press, 11-18.

[7] Chen, Z. M. (Ed.). (2001). Annuals of the University of International Business and Economics. Beijing: Press of University of International Business and Economics.

[8] Chen, J. P. (2010). Discussion on the problems of the newly established Business English Major -- emphasizing "English qualities" or "Business characteristics". Chinese University Teaching, 6, 45-48.

[9] Cowling, J. D. (2007). Needs analysis: planning a syllabus for a series of intensive workplace courses at a leading Japanese company. English for Specific Purposes, 26, 426-442.

[10] Dou, W. L. (2005). A comparative study of business English courses in universities. China Higher Education Research, 5, 90-92.

[11] Dudley-evans, T. \& M. J. St John. (1998). Development in English for specific purposes: a multi-disciplinary approach. Cambridge: Cambridge University Press.

[12] Ellis, M. \& C. Johnson. (1994). Teaching Business English. Oxford: Oxford University Press.

[13] English Group of the Teaching Guiding Committee for College Foreign Language Majors under the Ministry of Education, (2000). English Teaching Syllabus for English Majors in Higher Education, Beijing: Foreign Language Teaching and Research Press.

[14] Feng, M. \& C. P. SONG. (2011). Present situation of British international Business English major teaching and the enlightenment -- a case of international Business English major in Central Lancashire University of UK. Theory and Practice of Education, 31(2), 56-58.

[15] Fu, C. L. (2006). Discuss the orientation of business English major based on business content. International Business Studies, 1, $17-22$.

[16] Halliday, M. A. K., A. Mcintosh \& P. Strevens. (1964). The linguistic sciences and language teaching. London: Longman.

[17] He, Q. X., T. S. Yin, Y. S. Huang \& H. P. Liu. (1999). Thoughts on reform of FLT to FL majors. Foreign Language Teaching and Research, 117, 24-28.

[18] Hutchinson, T. \& A. Waters. (1987). English for specific purposes. Cambridge: Cambridge University Press.

[19] Johns, A. M. \& T. Dudley-evans. (1991). English for Specific Purposes: International in scope, specific in purpose. TESOL Quarterly, 25, 297-314.

[20] Li, J. (2014). Needs analysis: an effective way in Business English curriculum design. Theory and Practice in Language Studies, 4 (9), 1869-1874. 
[21] Louhiala-salminen, L. (1996). The business communication classroom vs. reality: what should we teach today? English for Specific Purposes, 15 (1), 37-51.

[22] Moslehifara, M. A. \& N. A. Ibrahim. (2012). English language oral communication needs at the workplace: feedback from human resource development (HRD) trainees. Procedia-Social and Behavioral Sciences, 66, 529-536.

[23] Munby, J. (1978). Communicative syllabus design. Cambridge: Cambridge University Press.

[24] Pickett, D. (1986). Business English: Falling between two stools. Comlon, 2, 2.

[25] Robinson, P. (1991). ESP today: a practitioner's guide. Hemel Hempstead: Prentice Hall International.

[26] Ruan, J. Z. (2005). Objectives and principles of business English courses in universities. Foreign Language World, 3 (General Serial No. 107), 26-31.

[27] Schleppegrell, M. \& L. Royster. (1990). Business English: an international survey. English for Specific Purposes, 9, 3-16.

[28] Simon, S. (2014). Enhancing the English oral communication skills of the $1^{\text {st }}$ year students of the Bachelor's degree program "Communication and Public Relations". Procedia-Social and Behavioral Sciences, 116, 2481-2484.

[29] Stanley, P. (2011). 4 Meeting in the middle? Intercultural adaptation in tertiary oral English in China. In L. X. Jin \& M. Cortazzi (Eds.), Researching Chinese learners: skills, perceptions and intercultural adaptations. London: Palgrave Macmillan, 93-118.

[30] St John, M. J. (1996). Business is booming: business English in the 1990s. English for Specific Purposes, 15 (1), 3-18.

[31] St. John, M. J. \& C. Johnson. (1996). Why this volume. English for Specific Purposes, 15, 1-2.

[32] Sun, C. L. \& W. Bao. (2010). A study of curriculum design for international business English. Journal of Shandong University (Philosophy and Social Sciences), 5 (1), 153-156.

[33] Wang, G. F. \& W. Xu. (1997). A preliminary study of Business English. In X. G. Ye (Ed.), Explorations into the teaching of Business English. Shanghai: Shanghai Jiaotong University Press, 3-8.

[34] Wang, L. F. (2012). On the orientation of Business foreign language discipline and academic research, Foreign Languages in China, 3, 34-39.

[35] Wang, L. F. \& L. Li. (2013). An investigation about the present ten years' situation of business English (2002-2011). Foreign Language World, 4, 2-10.

[36] Wang, L. F. (2015). The core problems of the construction of Business English major under the guidance of national standards. Foreign Language Education in China (Quarterly), 8 (1), 3-8.

[37] Weng, F. X. (2009). Business English study. Shanghai: Shanghai Jiaotong University Press.

[38] Wette, R. \& G. Barkhuizen. (2009). Teaching the book and educating the person: challenges for university English language teachers in China. Asia Pacific Journal of Education, 29(2), 195-212.

[39] Xie, Q. (2016). Business communication needs of English major undergraduates and curriculum development in a Chinese University. Asia-pacific Edu Res, 25 (4), 667 - 676.

[40] Xu, J., L. Dong \& X. P. Feng. (2011). Problems to be resolved in the construction of business English subject. Journal of Jixi University, 11 (3), 91-92.

[41] You, Y. M. \& W. B. Zhang. (2011). A survey of curriculum design of business English major in China. Journal of North China Institute of Water Conservancy and Hydroelectric Power (Social Science), 27 (1), 1-3.

[42] Zagan-zelter, D. (2010). Telling ELT tales out of school, teaching business English - a challenge both for students and academics. Procedia Social and Behavioral Sciences, 3, 245-250.

[43] Zhang, L. L. \& S. Wang. (2012). An empirical study on types of motivation in ESP learning among English majors. China ESP Journal, 3 (1), 33-42.

[44] Zhang, Y. Z. (2014). Business English curriculum development based on needs analysis. China after School Education, 10, 102-103.

[45] Zhang, Z. C. (2007). Towards an integrated approach to teaching Business English: a Chinese experience. English for Specific Purposes, 26, 399-410.

[46] Zheng, L.H. (2011). Needs analysis of business English for English majors in Zhejiang University. Social Sciences Education, April, 35-36.

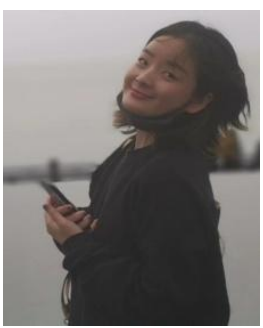

Bayan Ruan was born in Ningbo, China in 1987. She received her master degree in Intercultural Communication for Business and the Professions from The University of Warwick, UK in 2013. She is still a third year part-time EdD student in the University of Nottingham, Ningbo China. She also received Cambridge ESOL Level $5 *$ Certificate in Teaching English to Speakers of Other Languages (CELTA), and Award in Preparing to Teach in the Lifelong Learning (PTLL) from Nottingham, UK in 2011.

She is currently a teaching assistant in the School of Foreign Language Studies, Ningbo Institute of Technology, Zhejiang University, Ningbo, China. Her research interests include applied linguistics, discourse analysis, business English, intercultural communication, returnee teachers' professional identity construction. 